\title{
Zastosowanie napawanych płyt trudnościeralnych w naprawach maszyn podstawowych górnictwa odkrywkowego
}

\section{Application of cladded abrasive-resistant plates in repairs of opencast mining equipment}

\section{Streszczenie}

Intensywna eksploatacja współczesnych maszyn podstawowych górnictwa odkrywkowego pociąga za sobą znaczne zużycie ścierne przesypów w układzie transportu urobku. Warunki te wymagają podjęcia prac nad zastosowaniem materiałów odpornych na ścieranie. Materiały używane w lejach przesypowych poza wysoką odpornością na ścieranie powinny się również charakteryzować dostateczną wytrzymałością na obciążenia dynamiczne. Próby eksploatacyjne dowiodły, że najlepiej sprawdzają się płyty stalowe z napoiną trudnościeralną.

\section{Abstract}

The intensive exploitation of opencast mining machines involves a high wear of elements of bulk material transport systems. These conditions have forced users to try using different types of materials resistant to abrasion. Materials used in belt chutes, beyond high abrasion resistance, should also have sufficient strength to dynamic loads. Operation tests have shown that the best combination of the above demands meet the steel cladded wear plates with high resistant overlay.

\section{Wstęp}

PGE KWB Turów należy do najstarszych, a zarazem najtrudniejszych pod względem eksploatacyjnym, odkrywkowych kopalń węgla brunatnego w Polsce. Wcześniejsze pokłady węgla zalegały kilkadziesiąt metrów pod powierzchnią ziemi i aby je wydobyć, wystarczyło usunąć niewielką ilość nadkładu. Po wielu latach eksploatacji podstawowym złożem stał się węgiel zalegający na dużej głębokości, dostępny pod warstwą trudno urabialnego nadkładu, którego stosunek do wę-

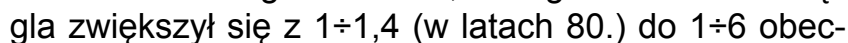
nie, powodując zarazem zwiększone zużycie elementów maszyn.

Warunkiem uzyskania zadowalających efektów techniczno-ekonomicznych w eksploatacji kopalni

Mgr inż. Tomasz Mucha, Konrad Bartkowiak - PGE GiEK S.A. KWB Turów. odkrywkowej jest dokładna znajomość cech technologicznych, czynników warunkujących przebieg procesu roboczego oraz czynników zakłócających ten proces. Podstawowy proces technologiczny eksploatacji odkrywkowej w zakresie usuwania nadkładu i skał płonnych obejmuje: urabianie, transport i zwałowanie. Do realizacji tego procesu wykorzystuje się: koparki, przenośniki taśmowe i zwałowarki (układ KTZ). Roczny czas pracy maszyny podstawowej wynosi $2 \div 4,5$ tys. $h$, a więc maszyny te są eksploatowane bardzo intensywnie. Często występujące skrajnie trudne warunki pracy znacznie przyśpieszają proces degradacji układu transportu urobku.

Trwałość projektowa maszyn podstawowych jest bardzo duża - wynosi 30 $\div 50$ lat. Zapewnienie tak dużej trwałości konstrukcji nośnej realizowane jest w oparciu o rozbudowany system norm obejmujących projektowanie, wykonawstwo i ograniczenia eksploatacyjne [1]. Nie opracowano jak dotąd podstaw normalizacyjnych określających wymagania dla elementów podlegających zużyciu ściernemu. Zużywanie 
elementów i zespołów konstrukcji pracujących w warunkach tarcia i obciążeń zmiennych (często o charakterze udarowym) stanowi od lat jeden z głównych problemów eksploatacyjnych maszyn górnictwa odkrywkowego. Dominującym procesem zniszczenia takich elementów jak: zęby, czerpaki, zsuwnie, przesypy, ogniwa gąsienicowe, sa procesy ujmowane w trybologii jako zużywanie ścierne. Elementy te podlegają częstym gruntownym remontom lub całkowitej wymianie, istotnie wpływa na koszty eksploatacyjne.

Cechy środowiska wywołującego zużywanie elementów koparek i zwałowarek są determinowane przez naturę, czyli są w praktyce nieregulowalne. Dlatego działania zmierzające do optymalizacji tych elementów muszą być skupione na doskonaleniu rozwiązań konstrukcyjnych i materiałowych [2]. Szczególną funkcję do spełnienia mają inżynierowie spawalnicy, gdyż właśnie technologie spawalnicze zapewniają najmniejsze koszty produkcji i eksploatacji. Wśród rozwiązań wykorzystujących technologie spawalnicze intensywnie rozwija się wytwarzanie i zastosowanie trudnościeralnych płyt napawanych, które chronią przed intensywnym zużyciem ściernym. Nie tylko udoskonala się procesy wytwarzania takich płyt, ale poszukuje się również materiałów na napoiny o optymalnych właściwościach przeciwściernych.

\section{Próby eksploatacyjne z użyciem materiałów odpornych na ścieranie}

W 2000 r. została wprowadzona do eksploatacji w KWB Turów zwałowarka ZGOT 11500, której duża wydajność przełożyła się bezpośrednio na intensywne zużycie ścierne elementów lejów przesypowych. Zamontowane przez producenta wykładziny wykonane ze stali 35SG nie zapewniały przebiegów międzynaprawczych. Aby uniknąć postojów awaryjnych na wymianę zużytych wykładzin, rozpoczęto poszukiwania innego rozwiązania.

Prowadzono próby eksploatacyjne z zastosowaniem materiałów takich jak: stale stopowe, żeliwa, tworzywa sztuczne, ceramika oraz płyty napawane.

Obiecująco zapowiadały się płyty wykonane ze stali martenzytycznej Hardox 400 i Hardox 500. W próbie eksploatacyjnej zamocowano je za pomocą spoin sczepnych w leju koła czerpakowego koparki KWK 1500s, w bezpośrednim sąsiedztwie płyt napawanych. Okazało się, że w strefie wpływu ciepła występuje (odmiennie niż przy spawaniu wszystkich dotychczasowych materiałów konstrukcyjnych) spadek twardości nawet do $50 \%$ w porównaniu ze stanem dostawy, przy bardzo dobrych właściwościach pozostałej części. Zwiększone zużycie ścierne na krawędziach płyt (porównywalne ze stalą S355JR) dyskwalifikuje je przy tym sposobie mocowania, koniecznym w większości zastosowań (rys. 1) [3].

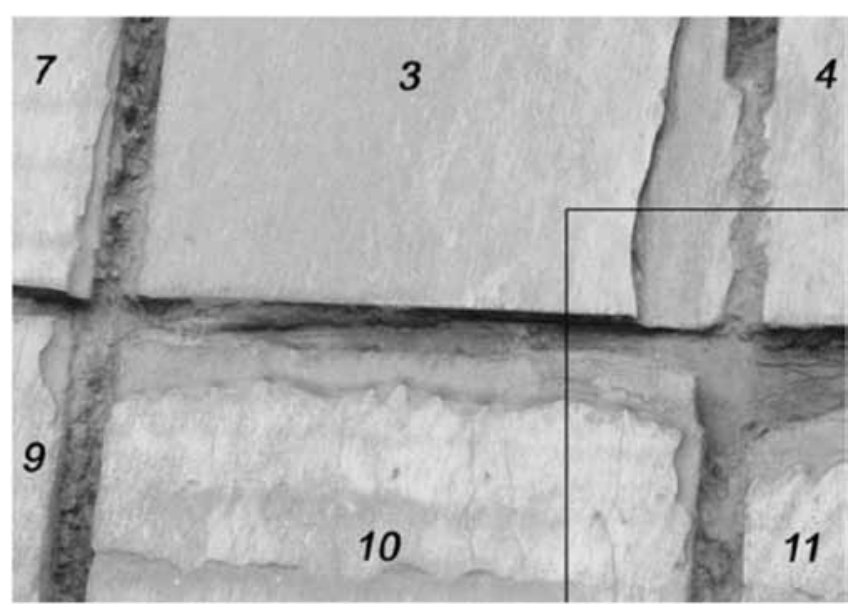

Rys. 1. Zużycie po $565 \mathrm{~h}$ - wyraźne zużycie płyty Hardox (nr 3) w strefie wpływu ciepła [3]

Fig. 1. Wear after 565 hours - visible wear of a Hardox (no. 3) plate in the heat affected zone [3]

W latach dziewięćdziesiątych ubiegłego wieku odbyły się próby eksploatacyjne z zastosowaniem płyt żeliwnych, odpornych na ścieranie i do pracy $w$ podwyższonej temperaturze, zamontowanych na zsuwni stałej leja koła czerpakowego. Właściwości żeliwa uniemożliwiły bezpośrednie mocowanie płyt techniką spawania. Dlatego też płyty umieszczono w specjalnie wykonanych ramach i umocowano je za pomocą nitów, a następnie bezpośrednio przyspawano do zsuwni. Płyty wykazały bardzo dobrą odporność na ścieranie, natomiast przy dużych obciążeniach dynamicznych następowały liczne pęknięcia i wykruszenia (rys. 2).

W 2010 r. w KWB Turów przeprowadzono próby z użyciem wykładzin lejów wykonanych z tworzyw sztucznych, z powodzeniem stosowanych w urządzeniach przesypowych kopalni węgla kamiennego. Zaletą wykładzin jest ich mała masa oraz odporność na przywieranie urobku w warunkach zimowych.

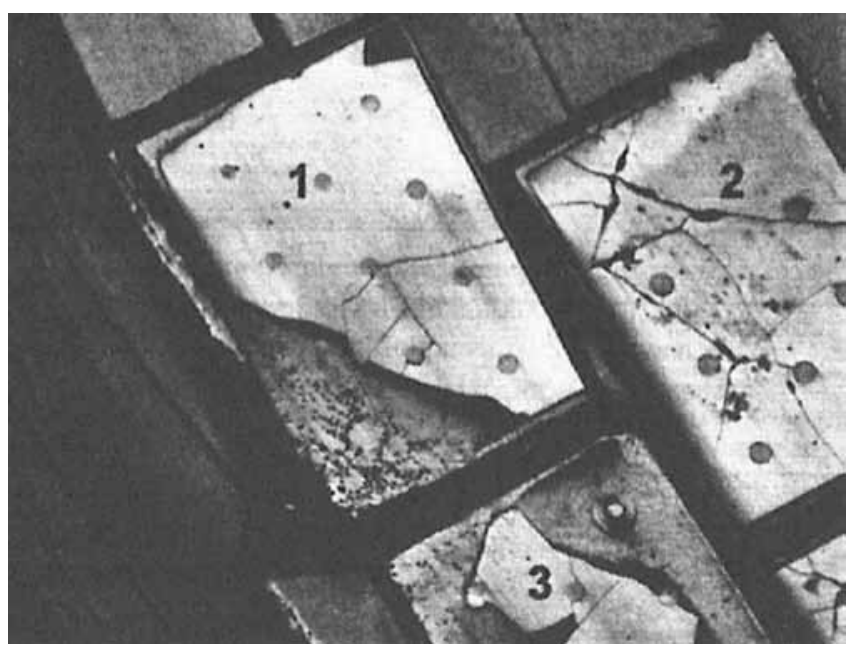

Rys. 2. Uszkodzenia płyt żeliwnych [4]

Fig. 2. Damage of cast iron plates [4] 
Mocowanie było możliwe tylko przy zastosowaniu połączeń śrubowych, a uniemożliwiało ich zastosowanie w większości przypadków. Bardzo duże zużycie ścierne wykładzin z tworzyw sztucznych w stosunku do dotychczas używanych materiałów dyskwalifikuje zasadność dalszych prób.

W przeszłości podjęto również próby zastosowania wykładzin ceramicznych zsuwni lejów. Bardzo dobre właściwości przeciwścierne ceramiki nie idą niestety w parze z odpornością na obciążenia dynamiczne następowało ich całkowite zniszczenie w kontakcie ze skałą zawartą w urobku.

W KWB Turów w 2000 r. podjęto próby zastosowania płyt stalowych $\mathrm{z}$ napoiną trudnościeralną w lejach przesypowych nowo wybudowanej zwałowarki o wydajności $11500 \mathrm{~m}^{3} / \mathrm{h}$. Trwałość tych płyt okazała się trzykrotnie większa od wykładzin wykonanych ze stali 35SG, powszechnie stosowanych wówczas w elementach maszyn podstawowych i przenośników taśmowych poddanych zużyciu ściernemu. Dobre wyniki próby spowodowały powszechne zastosowanie tego rozwiązania we wszystkich lejach przesypowych maszyn podstawowych KWB Turów.

Płyty z napoiną trudnościeralną wykonywane są przez pokrycie łatwo spawalnej blachy nośnej warstwą odporną na zużycie. Swoje właściwości zawdzięczają one występowaniu w strukturze warstwy wierzchniej twardych węglików chromu typu $\mathrm{M}_{7} \mathrm{C}_{3}$ [4].

Doświadczenia zdobyte przez wiele lat eksploatacji płyt z napoiną trudnościeralną skłoniły służby techniczne kopalni do podjęcia próby z zastosowaniem ich w częściach wirujących przesypów koparek, takich jak bęben odbojowy. Przed podjęciem ostatecznej decyzji o eksperymencie dokonano szczegółowej analizy obciążeń. Zasadnicza różnica to zdecydowanie większe obciążenia dynamiczne powodowane wysokością, z jakiej struga urobku uderza w poszycie bębna, mogące powodować pęknięcia i wykruszenia napoiny.

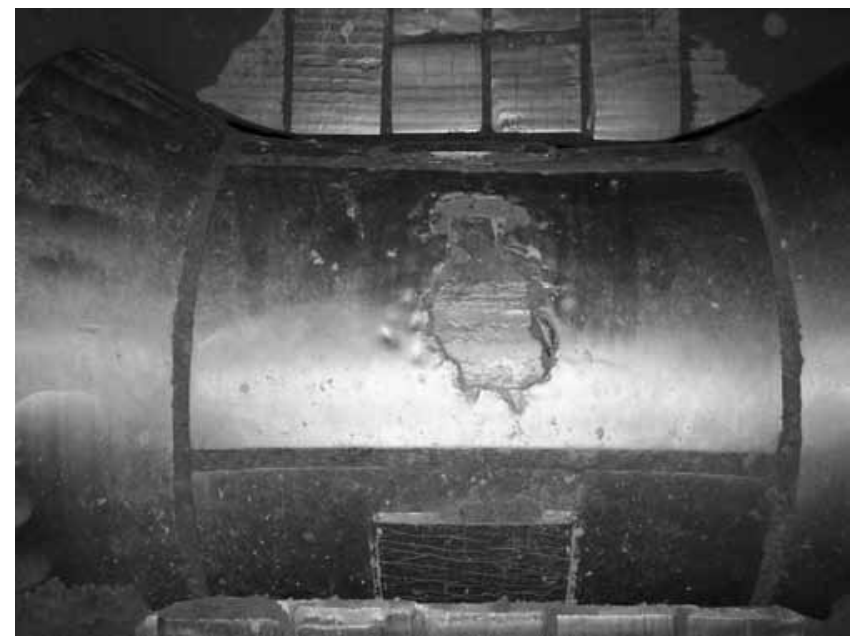

Rys. 3. Zużyta okładzina po $1200 \mathrm{~h}$ pracy

Fig. 3. Lining worn after 1200 hours of operation
Bęben odbojowy, o średnicy 1020 mm, w części środkowej jest zabudowany $w$ przesypie centralnym koparek KWK 1500s. Jak nazwa wskazuje, ma on za zadanie przyjęcie uderzenia strugi urobku z przenośnika podającego $z$ wysokości ok. $5 \mathrm{~m}$. Ruch obrotowy bębna ma też nadać kierunek oraz prędkość początkową transportowanej strudze urobku. Zabezpieczenie bębna odbojowego przed zużyciem ściernym było realizowane za pomocą okładzin ze stali S355JR.

Największe zużycie ścierne okładzin bębna odbojowego występuje w części środkowej walca oraz na styku elementów stożkowych z walcem (rys. 3).

W poprzednim rozwiązaniu konieczna była pracochłonna wymiana wszystkich elementów poszycia bębna. Opracowana dokumentacja uwzględnia możliwość wymiany tylko zużytych części przez zastosowanie 24 elementów napawanych w części walcowej oraz 32 w częściach stożkowych (rys. 4). Zastosowano także blachę gruntową, chroniącą zasadniczą konstrukcję bębna przed zniszczeniem podczas wymiany okładzin.

Doświadczalne wykładziny bębna odbojowego wykonano techniką dwuwarstwowego napawania blachy gruntowej S355JR. Przekrój poprzeczny blachy gruntowej wynosi $8 \mathrm{~mm}$, a napoin 2x4 $\mathrm{mm}$.

Próby wykonane z użyciem nowych wykładzin bębna odbojowego wykazały zwiększoną trwałość w stosunku do wykładzin bez napoiny:

- 3-krotnie części środkowej walca,

- 4-krotnie części skrajnych walca,

- 7-krotnie części stożkowych.

Podczas eksploatacji wystąpiły wykruszenia napoiny podczas urabiania rumoszu i zakamienionego urobku. Tego typu uszkodzenia ze względu na pozostałą blachę gruntową nie kwalifikowały wykładzin do natychmiastowej wymiany i w większości przypadków pozwalały na wymianę podczas najbliższego remontu planowego koparki.

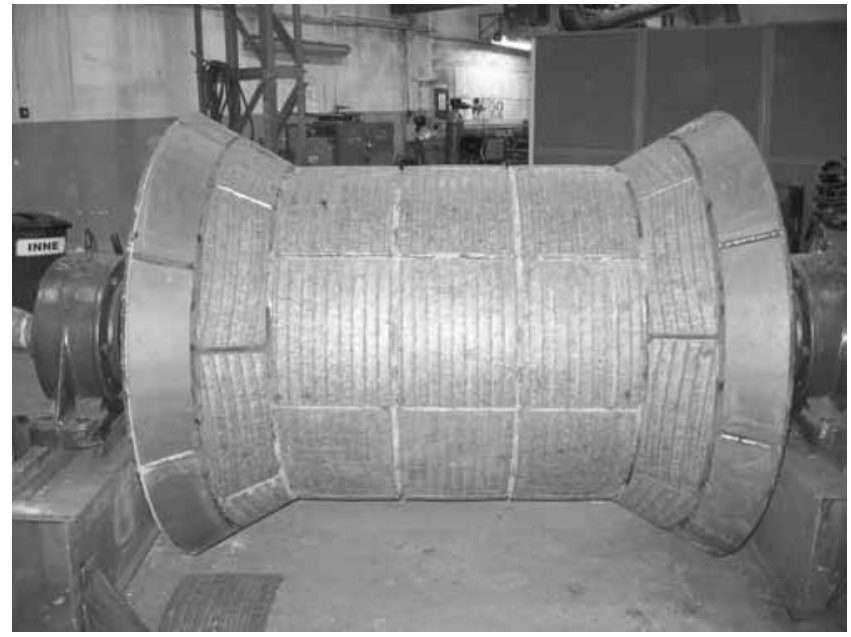

Rys. 4. Bęben odbojowy z doświadczalnymi okładzinami trudnościeralnymi

Fig. 4. Impact drum with experimental lining made of cladded wear plates 


\section{Podsumowanie}

Współczesne tendencje rozwojowe w budowie maszyn i urządzeń zakładają coraz większe osiągi, co pociąga za sobą intensyfikację procesów zużycia i degradacji maszyn. Doświadczenia i próby z różnego rodzaju materiałami odpornymi na zużycie ścierne pozwoliły na zakwalifikowanie ich do grup przydatnych oraz nieznajdujących zastosowania w KWB Turów. Ceramika, pomimo dużej odporności na ścieranie, okazała się kompletnym fiaskiem ze względu na minimalną odporność na obciążenia dynamiczne. Dobre wyniki uzyskane w kopalniach dołowych węgla kamiennego z użyciem tworzyw sztucznych okazały się niewystarczające $w$ kontakcie $z$ nadkładem w KWB Turów. Próby przeprowadzone z płytkami wykonanymi z żeliwa odpornego na ścieranie potwierdziły jego przydatność, ale tylko w przypadku urobku niezawierającego dużych kamieni, skał itp. Bardzo obiecująco wypadły próby z zastosowaniem stali Hardox 400 i Hardox 500, gdzie potwierdzono ich bardzo dobre właściwości przeciwścierne, lecz ujawnił się problem utraty właściwości w strefach wpływu ciepła.
Najlepszym z dotychczasowych rozwiązań w KWB Turów okazały się płyty $z$ napoiną trudnościeralną. Uzyskano bardzo dobre właściwości przeciwcierne oraz zadowalającą odporność na obciążenia dynamiczne, podczas gdy przy zastosowaniu innych materiałów jedna $z$ wymienionych cech okazywała się niewystarczająca. Zaskakująco dobre wyniki uzyskane przy zastosowaniu tych płyt jako okładziny bębna odbojowego potwierdzają zasadność ich stosowania. Podstawowym problemem występującym w płytach napawanych jest skłonność do pękania i odpadania napoiny od warstwy podkładowej. Również zmniejszenie grubości blachy gruntowej, a co za tym idzie możliwość zwiększenia grubości napoiny, wpłynęłoby na zwiększenie trwałości wykładzin. Jest to możliwe do zrealizowania przy uzyskaniu odpowiedniej pierwszej warstwy napoiny (strefy buforowej) oraz zastosowaniu trzeciej warstwy napoiny - niestosowanej w tych rozwiązaniach ze względu na kruchość całej napoiny.

\section{Literatura}

[1] Kowalczyk M.: Podstawy normowe projektowania ustrojów nośnych maszyn podstawowych górnictwa odkrywkowego, Problemy Maszyn Roboczych nr 8/1997.

[2] Babiarz S., Dudek D.: Kronika awarii i katastrof maszyn podstawowych w polskim górnictwie odkrywkowym, Oficyna Wydawnicza Politechniki Wrocławskiej, Wrocław 2007.
[3] Cegiel L., Konat Ł., Pawłowski T., Pekalski G.: Stale Hardox - nowe generacje materiałów konstrukcyjnych maszyn górnictwa odkrywkowego. Węgiel Brunatny nr 3/56, Bogatynia 2006.

[4] Mucha T.: Zastosowanie napawanych płyt trudnościeralnych w naprawach części maszyn górnictwa odkrywkowego, Praca magisterska, Wrocław 2009.

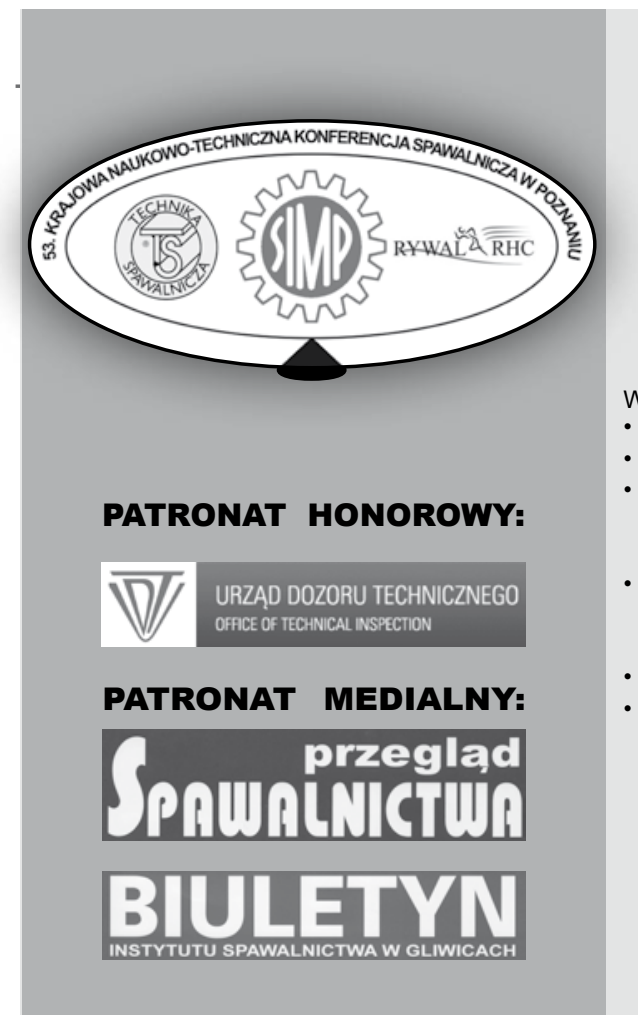

Mamy przyjemność zaprosić Państwa do uczestnictwa w

53. KRAJOWEJ NAUKOWO-TECHNICZNEJ KONFERENCJI SPAWALNICZEJ pt. „Nowe kierunki w procesach spajania i cięcia metali”

organizowanej w dniach 12 - 14 października 2011 r. w Poznaniu przez:

\section{SIMP - SEKCJA SPAWALNICZA Oddział w Poznaniu TECHNIKA SPAWALNICZA POZNAŃ \\ RYWAL RHC Spółka z o.o. w Warszawie}

W programie m.in.:

referaty z robotyki procesów spajania i cięcia

prezentacja nowych technologii i materiałów

referaty techniczne dotyczace m.in:

- $\quad$ konstrukcji stalowej Stadionu Miejskiego w Poznaniu

- konstrukcji iglicy Stadionu Narodowego w Warszawie wyjazdy techniczne

- VOLKSWAGEN POZNAŃ

STADION MIEJSKI

WYSTAWA URZADZEŃ I SPRZETU

POKAZY ROBOTÓW!

\section{ZAREZERWUJ SOBIE CZAS !}

W celu uzyskania szczegółowych informacji prosimy o kontakt:

miroslaw.nowak@techspaw.com.pl andrzej.wisniewski@techspaw.com.pl ryszard.andrzejewski@techspaw.com.pl ryszard.wesolowski@rywal.com.pl k.ptak@taskoprojekt.com.pl tel.: 602118401

tel.: 602118404

tel.: 602603313

tel.: 609061311

tel.: 691865598 